\title{
Civic ecology practices: insights from practice theory
}

\author{
$\underline{\text { Marianne E. Krasnv }}^{1}, \underline{\text { Philip Silva }}^{1}, \underline{\text { Cornelia Barr }}^{2}, \underline{\text { Zahra Golshani }}^{3}, \underline{\text { Eunju Lee }}^{1}$, Robert Ligas $^{4}, \underline{\text { Eve Mosher }}^{5}$ and Andrea Revnosa $^{6}$
}

\begin{abstract}
Our aim was to explore the use of practice theory as an approach to studying urban environmental stewardship. Urban environmental stewardship, or civic ecology practice, contributes to ecosystem services and community well-being and has been studied using social-ecological systems resilience, property rights, communities of practice, and governance frameworks. Practice theory, which previously has been applied in studies of consumer behaviors, adds a new perspective to urban stewardship research, focusing on how elements of a practice, such as competencies, meanings, and physical resource, together define the practice. We applied practice theory to eight different civic ecology practices, including oyster gardening in New York City, a civil society group engaged in litter cleanup in Iran, and village grove restoration in South Korea. Our analysis suggests that in applying practice theory to the civic ecology context, consideration should be given to social and communication competencies, how meanings can motivate volunteers and sustain practice, and the nature of the resource that is being stewarded. Future studies may want to focus on how practice elements interact within and vary across practices and may be used to more systematically analyze and share ideas among diverse civic ecology practices.
\end{abstract}

Key Words: civic ecology; practice theory; stewardship; urban

\section{INTRODUCTION}

In addition to formally designed city parks, locally driven stewardship practices such as community gardening, neighborhood tree planting, and habitat restoration help provision ecosystem services and maintain biodiversity in cities (Goddard et al. 2010, Pataki et al. 2011, Sassen and Dotan 2011, Elmqvist et al. 2013, Krasny et al. 2014b). Further, active engagement in stewardship may lead to positive outcomes for participants and their communities (Barthel 2006, Andersson et al. 2007, Krasny and Tidball 2012) and contributes to a larger civic environmental movement (Sirianni and Friedland 2005). Thus, examining these community-based stewardship or "civic ecology" practices (Krasny and Tidball 2012, 2015), and the variety of forms they take, is important to understanding how humans can become a positive force in provisioning ecosystem services and contributing to community well-being in cities and across human-impacted landscapes more broadly.

Research into civic ecology practices falls into a tradition dating to the 1980 s, when scholars distinguished participatory green spaces created by community residents from more formal, professionally designed spaces initiated by municipalities (Francis et al. 1984). Recently, European scholars used a property rights lens to view the biodiversity and ecosystem services contributed by "urban green commons" (Colding et al. 2013), and U.S. researchers found that collaboration among community, nonprofit, and government environmental stewardship initiatives is important in understanding urban environmental governance (Svendsen and Campbell 2008, Fisher et al. 2012). Further, a growing group of scholars has described mechanisms through which allotment gardening, community forestry, and other civic ecology practices in Europe, Africa, and the United States contribute to urban social-ecological systems resilience in the face of socioeconomic decline and major destructive events such as hurricanes. These resilience mechanisms include enabling expression of social-ecological memories (Barthel et al. 2010, 2014), ritual and symbolism (Tidball 2014), and memorialization
(Tidball et al. 2010, Svendsen and Campbell 2014); providing sites for social and environmental learning (Bendt et al. 2013, Krasny et al. 2013); and provisioning ecosystem services and promoting cultural and biological diversity (Andersson et al. 2007, Colding and Barthel 2013).

Whereas social-ecological systems resilience provides an important lens through which to understand the emergence of civic ecology practices and their contributions to larger systems, it has been critiqued for applying ecological concepts to social phenomena without sufficient attention to social theory (Davidson 2010). In addition, studies using the social-ecological resilience framework generally focus on one or two aspects of a practice, e.g., social-ecological memories (Barthel et al. 2014), rather than analyzing the practice as a whole. Thus, we build on previous work in urban environmental stewardship by applying a socio-cultural theoretical framework that focuses specifically on practice as the unit of analysis to compare multiple civic ecology practices. In particular, we draw from practice theory (Schatzki 2000, Reckwitz 2002) to examine how various elements of practice, including those reflecting the competencies of participants, the meanings participants attribute to their practices, and the physical or biological resource that is the focus of their stewardship activities, shape their practices.

In short, our purpose is to explore practice theory as an approach to studying urban environmental stewardship. To accomplish our goal, we first review the literature on practice theory and discuss its potential applications to civic ecology practices. We also point out some gaps in practice theory, which previously has been used in consumer studies, when applied to hands-on stewardship, including lack of attention to intentional behaviors and to natural resources. Next we ask: How do three elements of practice, i.e., competencies, meanings, and resource, differ across multiple civic ecology practices? The cases we have covered include four previously unreported practices: habitat restoration in WinstonSalem, North Carolina; volunteer tree-planting in metropolitan

${ }^{1}$ Civic Ecology Lab, Department of Natural Resources, Cornell University, ${ }^{2}$ Gateway Environmental Initiative, ${ }^{3}$ University of Illinois at UrbanaChampaign, ${ }^{4}$ Five Rivers MetroParks, ${ }^{5}$ Seeding the City, ${ }^{6}$ Tusten Heritage Community Garden 
Dayton, Ohio; community gardening in a small city in upstate New York; and rooftop gardening in New York City (NYC). We also include four practices, i.e., Nature Cleaners in Iran, village grove restoration in South Korea, oyster gardening in NYC, and natural area stewardship in Ithaca, New York, that have been reported in more depth elsewhere. Based on our comparative analysis of the elements across the eight practices, we suggest refinements in practice theory as applied to studies of civic ecology and related hands-on stewardship initiatives and discuss its utility in informing research and stewardship practice in cities.

\section{BACKGROUND}

\section{Practice theory}

Practice theory views practices as the core unit of analysis and thus offers a middle ground between individual agency or behavior and social or institutional structures (Reckwitz 2002, Hargreaves 2011). It suggests that to foster more environmentally friendly consumer and other behaviors, we should no longer focus on 'individuals' attitudes, behaviors and choices, but instead on how practices form, how they are reproduced, maintained, stabilized, challenged and ultimately killed-off; on how practices recruit practitioners to maintain and strengthen them through continued performance, and on how such practitioners may be encouraged to defect to more sustainable practices" (Hargreaves 2011:84). In prioritizing practices over individuals, practice theory claims that features of individuals, such as the activities in which they engage, their skills, interactions with others, identities, and interpretations or meanings, arise from their participation in social practices (Schatzki 2000).

Practices are composed of multiple elements and their interactions. However, practice theory scholars diverge on the elements of practice worthy of study (Gram-Hanssen 2011). For example, authors variously describe the elements holding practices together as understandings, procedures, engagement, and items of consumption (Warde 2005); know-how and embodied habits, institutionalized knowledge and explicit rules, engagements, and technologies (Gram-Hanssen 2011); practical understanding, rules, teleo-affective structures, and general understandings (Schatzki 2002); sayings, doings, and relatings (Kemmis and Mutton 2012); or material, skill, and image (Pantzar and Shove 2010). This lack of agreement suggests that rather than a unified theory, practice theory is most useful as a critical or analytical approach to the study of consumption and other human activities (Schatzki 2000, Gram-Hanssen 2011).

Miettinen et al. (2012) critique practice theory on the grounds that its focus on embodied habits that remain static limits its usefulness in understanding change in practice over time. To address this issue, these authors suggest using the related activity theory, with its emphasis on transformation of material and cultural artifacts leading to change in activity or practice (Engeström et al. 1999), and the theory of expansive learning, which focuses on reflection as a means to expand learning situated in activity (Engeström 1987). However, a number of empirical studies drawing on practice theory do describe the emergence of practices and how they evolve over time, generally through examining how the elements holding practices together change (Shove and Pantzar 2005, Pantzar and Shove 2010, Gram-
Hanssen 2011, Kemmis and Mutton 2012). Such studies are closely linked to research focusing on transitions to more environmentally friendly lifestyles and on the creation and spread of social innovations. For example, Seyfang et al. (2010:8) use practice theory to view how innovations are generated in civil society, i.e., grassroots innovations, "as new skills are developed to address specific challenges, as new images or meanings are adopted, and as the stuff of practices breaks down, is improved, gets replaced or is simply used in novel ways." Through in-depth studies of these processes, practice theory is said to expand on multilevel theories, which argue that innovations spread when destabilization of the existing order creates windows of opportunity (Geels and Schot 2007, Shove and Walker 2010). The notion that crises and disturbance allow space for innovations in resource management and educational practices to emerge is similarly a focus of the social-ecological resilience and related adaptive comanagement literature (Olsson et al. 2007, McPhearson and Tidball 2014). Practice theory adds to these explanations by helping us understand the factors involved in the emergence and growth of new social processes such as grassroots or social innovations (Seyfang et al. 2010).

An important aspect of the process of developing both technological and social innovations is coproduction by consumers and researchers or practitioners and policy makers (Young Foundation 2012). Using a practice theory lens, Pantzar and Shove (2010) describe how the practice of Nordic walking, i.e., walking for exercise using two sticks, emerged and spread as a result of middle-aged women in Finland reimagining the manufacturer's intended elite sport purpose of the walking sticks (i.e., material element in practice theory). The women also imposed their own meanings about nature, health, and well-being (i.e., meaning element) through their recreational walking (i.e., doing element). Similarly, Seyfang and Haxeltine's (2012) notion of grassroots innovations suggests a strong role for civil society actors in generating new practices. Further, participation in the production of practices or innovations may be one means by which practices become significant and meaningful for participants. For example, Kemmis and Mutton (2012) describe how the actions, discourses, and interpersonal relationships formed through organic gardening became meaningful for, and thus valued by, the participants. In that positive meanings associated with practices may facilitate participation, this research would suggest an alternative to approaches that attempt to influence environmental behaviors through negative messaging where little attention is paid to positive meanings or to the elements holding a practice together, and in fact the desired behaviors may have threatening meanings for target audiences leading to unwillingness to adopt them (cf. Dickinson 2009, Spaargaren 2011).

It is important to distinguish between Wenger's notion of communities of practice, which focuses on situated learning that occurs through engagement and enculturation in a practice (Wenger et al. 2002), and practice theory, which is a more encompassing way of viewing and understanding a broad range of social phenomena. Practice theory argues that the locus of the social is found in practices, i.e., networks of relationships between people, things, and activities. In this way, practice theory is more of a worldview or paradigm that lies between structuralism, 
which focuses on social structures as determining human behaviors, and postmodern approaches, which emphasize human agency (Reckwitz 2002, Schatzki 2002).

\section{Practice theory and civic ecology practices}

Practice theory has been used widely in studies of consumer behaviors, with a focus on how consumption practices emerge and change over time (Warde 2005, Gram-Hanssen 2010, 2011, Pantzar and Shove 2010). Although we are not aware of previous studies applying practice theory to hands-on stewardship, three aspects of practice and related theories suggest that they may prove useful in the civic ecology context. First, practice theory integrates multiple elements that have previously been addressed separately in writing about civic ecology practice. Second, Spaargaren (2011) draws on the work of prior authors to suggest that practice theory offers an alternative to a negative focus on behaviors that people should not do by encompassing practices that create positive emotional energy; this notion of positive engagement is consistent with writing about civic ecology practice (Tidball and Stedman 2013, Tidball 2014). Finally, civic ecology practices have been referred to as "social-ecological innovations" (Ernstson and Elmqvist 2011) that emerge through the efforts of citizen activists in communities stricken by sudden disasters or experiencing more gradual deterioration of social and natural capital (Tidball et al. 2010, Tidball and Krasny 2014). Although earlier writings about practice theory focused on more static behaviors, recent authors have used a practice theory lens to explore in greater depth how innovations emerge, including through coproduction of practices by participants and policy makers (cf. Pantzar and Shove 2010, Seyfang and Haxeltine 2012), which may add to our understanding.

In this first attempt to apply practice theory to civic ecology practices, we decided to limit the practice elements to three, drawing from the work of Pantzar and Shove (2010), who in their studies of consumer culture have focused on competencies, meanings, and product. Recognizing that practices focusing on stewardship of a physical (i.e., land or water) or biological (i.e., plant or animal) resource differ from consumer practices that are the subject of previous work, we adapt these three elements as follows. First, practice theory has often referred to "embodied habits" or less reflective practices (Schatzki 2000, Reckwitz 2002), whereas Pantzar and Shove (2010) have expanded this work to focus on participants' more intentional behaviors or competencies, in their case Nordic walking. We further expand existing perspectives to incorporate a broad suite of competencies needed for engaging others in stewardship practice. Second, parallel to Pantzar and Shove (2010), who talk about meanings related to objects, i.e., walking sticks for the fit or for the infirm, and doing, i.e., walking for fun or for fitness, we are particularly interested in meanings related to place and practice. We draw from a significant body of work on sense of place, symbolism, and social-ecological memories in civic ecology practices (Barthel et al. 2010, 2014, Kudryavtsev et al. 2012, Tidball 2014). Finally, the product or material element in studies of consumption practices has focused on such things as walking sticks or electric appliances; we have replaced consumer items with the land, water, or biological resource that is the focus of stewardship activities.
We define the practice elements used in analyzing each civic ecology practice as follows. Competencies are the skills the leaders bring to the practice. Meanings encompass social and ecological values attributed to the resource that is the focus of the practice or to the practice itself. Resource refers to the physical piece of land or stretch of water or the plants or wildlife that are the focus of the practice.

\section{METHODS}

We carried out our research as part of a professional development program for environmental educators and related professionals. More specifically, the first four cases were drawn from the final reports of students participating in an online course, entitled "Civic Ecology: Blending Theory and Practice," taught by the first and second authors (M.E.K. and P.S.) in spring 2013. Course participants answered a series of guided questions about the emergence and change over time of a civic ecology practice that they led, the components of the practice (i.e., learning, health and well-being, social-ecological memories, ecosystem services, and social capital), and the interactions of the practice with governance and social-ecological systems (Krasny and Tidball 2012). At the end of the course, participants synthesized their reflections on the guided questions into a final report describing their practice.

The first author then read the reports and the previously published papers about the four other cases for evidence of the three practice theory elements. She developed descriptors for the three elements for each of the cases and developed summaries of each practice based on the reports and papers. She then shared the descriptors and summaries with the authors of the reports and the authors of two of the papers who offered feedback before the final descriptors were generated. The first author was the lead author for the last two cases, and thus the practice element descriptors for these practices were not "checked" with other authors.

\section{CIVIC ECOLOGY PRACTICE CASE DESCRIPTIONS}

\section{Gateway Environmental Initiative}

Gateway Environmental Initiative (GEI) started as an effort to acquire a 19-acre former industrial site near downtown WinstonSalem, North Carolina, and convert it to a nature center. Despite the site's designation as a brownfield, it supports a range of plants and wildlife. Although GEI's priority to date has been advocacy and raising funds to purchase the property, the leader (coauthor C.B.) and her growing group of collaborators have initiated educational and stewardship activities, such as a Family Nature Club and a species inventory on the site.

GEI grew out of neighborhood opposition to commercial development in 2006-2007. Early on, C.B. fought the prevailing attitude that development was inevitable. Over time, city officials, the broader community, and even the property seller have embraced the idea that a nature center will be an asset to the area, and C.B. has amassed a large group of city, nonprofit, and private partners who support GEI's work (Fig. 1).

C.B. developed a metaphor of connectivity around the stream flowing through the site, which has been critical to galvanizing interest: "... just as Salem Creek connects our two main water sources (Salem Lake and the Yadkin River), the future nature 
Fig. 1. Gateway Environmental Initiative partnerships, current and future, developed by practice leader C.B.

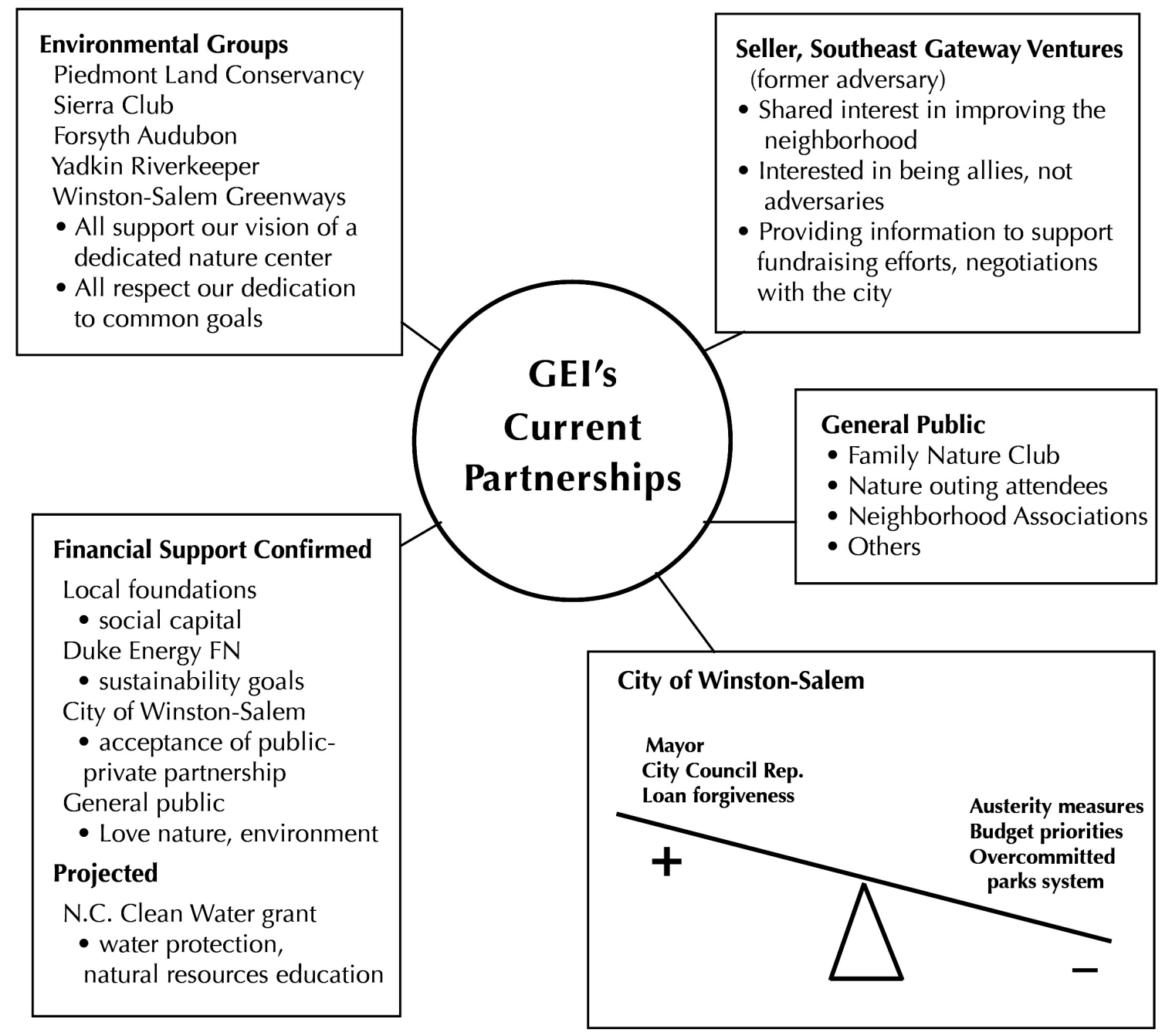

\section{Future Projects \& Potential Partners}

- Remove invasive species / Boy Scouts, civic groups

- Soil bioremediation / WM, EPA

- Build nature education building / local architects, lumber suppliers

- Build wildlife viewing pavilion / lumber suppliers, civic groups

- Bird \& butterfly habitat / garden clubs

center will be a resource that brings together the diverse neighborhoods along Salem Greenway" (participant response, 2013, online course). Further, C.B. articulated a vision of creating "a center that demonstrates how nature can regenerate itself, a symbol of hope and empowerment in a world where, on the global scale, much of the environmental news is disheartening" (participant response, 2013, online course). Articulating this message seems to strike a chord in people, as evidenced by the gradual buy-in from multiple constituencies. With land acquisition close to a reality, C.B. considers GEI's most important achievement the growing local awareness of green infrastructure as a valuable resource. 


\section{Five Rivers MetroParks}

Five Rivers MetroParks (FRMP) is an offshoot of a state government agency that manages former agricultural land along rivers flowing through Dayton, Ohio. FRMP employee R.L. (coauthor) leads volunteer stewardship efforts to expand the existing forest lands, including a Master Silviculturist program to train volunteers and staff in ecology and forest renewal techniques; Tree Corps volunteers who assist in seed collection, seedling production and planting, and site maintenance; the Forest Foster Families program through which volunteers care for seedlings; and deer and invasive plant management. FRMP is unique among our cases because it focuses on a volunteer program run by a regional government agency, rather than an effort emerging through the efforts of civil society actors.

R.L. actively supports volunteers, e.g., through recognition dinners, social media, and conducting activities that promote intergenerational bonding among children and adult stewards, but has spent little time joining forces with other groups. During the tree-planting activities, people from different generations engage in storytelling and sharing of memories, and memories are also created through the volunteer experiences. Reminiscing and recounting stories enables volunteers to visualize how their practice has changed over the years, incorporate traditional stewardship methods, and express their feelings of connection to the trees.

\section{Tusten Heritage Community Garden}

The Tusten Heritage Community Garden in the town of Narrowsburg, New York, is at the core of leader A.R.'s (coauthor) larger vision to transform the landscape and economy of the surrounding Delaware River region. Through multiple community events that bring people together over shared interests in food and community improvement, A.R. hopes to break "layers of distrust" among traditional residents and newcomers to the region and create an "open forum for the sharing of knowledge, skills, and friendship" (participant response, 2013, online course). Further, she envisions how her Narrowsburg revitalization practices will stimulate a future regional network of similarly minded communities along the Delaware River that are able to stem "a tide of environmental destruction," i.e., hydraulic fracking, and turn "it into waves of progress and reform" (participant response, 2013, online course). Thus, the broader practice includes not only the community garden and food production, but also public events, education, and creating "an aesthetically pleasing and mutually nurturing ecosystem out of scarred land" (participant response, 2013, online course). A.R. has forged a large network of organizations, including Big Eddy Farm Stand, i.e., restaurant-supported agriculture; the Tusten Local Development Corporation Board; a local community college; an organization converting a vacant school into a food hub and innovation center; and 15 other environmental and art nonprofits.

Social-ecological memories play a role in that the garden seeks to redirect the town's future by remembering past agricultural traditions and by helping youth and other local residents raise heirloom vegetables and indigenous Lenape corn and beans. Further, the symbolic element of place is captured in names like "heritage" garden and "Big Eddy" farm stand, the former hamlet name for Narrowsburg, referring to the deepest part of the Delaware River.

\section{Seeding the City}

Seeding the City (STC) is the vision of artist E.M. (coauthor) who works across the boundaries of civic ecology, urban discovery, and participatory acts of intervention. STC's resource is a dispersed network of rooftop gardens in NYC, which E.M. views as "rooftop occupations" (participant response, 2013, online course). E.M. began creating green roofs with a small group of key advisers and then partnered with organizations, e.g., a homeless shelter, preschools, a museum, and a youth environmental organization, to conduct workshops and broaden implementation. A green roof modular gardening system designed for low-moisture and high-heat rooftops has enabled this practice to emerge and grow.

E.M. has a larger vision for how the rooftop modular gardens will transform the city, through changing the way that transient and other residents understand their living space and view themselves as leaders in the urban greening movement. She also sees her project as creating a sense of community and a sense of place among apartment dwellers in NYC, who lacking other gathering space, turn to their rooftops for parties, eating, and other shared experiences and form small "islands of community up in the sky" (participant response, 2013, online course). On holidays like the Fourth of July, people celebrating on rooftops can view neighboring rooftop celebrants, and E.M. envisions STC gardens as helping connect people across buildings. STC modules also address issues related to "elasticity" of place of city dwellers; renters can move their green roof modules from one building to another. Thus, the gardens serve as a place maker regardless of the location one currently resides. Finally, E.M. envisions that the rooftop gardening practice will create connections to the natural world in a dense urban environment.

\section{Nature Cleaners, Iran}

Kazem Nadjariun founded Nature Cleaners in June 2012, during a trip to a scenic lake in northern Iran (Golshani and Krasny 2013, Krasny and Tidball 2015). He and his friends, alarmed by trash surrounding the lake, decided to clean up the litter. Photos of the cleanup that Nadjariun posted on Facebook precipitated interest among Iranians tired of littering, and the first Nature Cleaners cleanup event took place in Tehran the following week. Subsequently, Nadjariun created Nature Cleaners groups in all 31 Iranian states, operating under their own leaders and sometimes a decision-making council, with advice and guidance from Nadjariun. Nature Cleaners' goals include cleaning trash from nature, raising awareness of keeping nature clean and of reducing trash and waste, and recycling trash collected at cleanup events. In the 16 months after Nature Cleaners was initiated, 450 cleaning events were held throughout the country. The Facebook site, which is used to share local and nationwide events, includes 40,000 members, about 3000 of whom have been active in cleanup events (Golshani and Krasny 2013).

Nature Cleaners conducts cleanups in popular parks, historic sites, and other open space during times when many people congregate so as to educate and engage others. The reaction of passersby has been favorable, indicating a pent-up interest in cleaner public spaces. Nature Cleaners has conducted additional 
activities, such as creating a recycling exhibit after a cleaning event, recycling bottle caps to raise money to buy a wheelchair for charity, and creating art objects using recycled trash, and it plans to hold educational classes for the public.

The activities carry important social meanings in addition to cleaning up nature and educating onlookers. Facebook posts refer to connecting with others, creating community, building networks, and becoming a "family." Another meaning visible on Facebook and through participating in events is how the participants feel that together they are having a larger impact, doing something for their country, and even cleaning their country more profoundly than picking up litter by being part of a larger movement. They also feel as if they are learning social skills, responsibility, and teamwork, which is seen as leading to a good future for Iran. Further, some participants have constructed a new identity as nature cleaners; for example, when they go on holidays, they post photos of themselves cleaning nature.

Nadjariun helps participants in the state chapters learn to work together, uploads photos onto Iran's slow Internet, and wades through comments posted to Facebook to remove any political or religious commentary. He has a vision of clean nature and creating a culture of cleaning up trash and caring for nature, which he conveys by posting educational and awareness messages on Facebook and through his comments meant to encourage participants. Nadjariun is networked with the head of Iran's Environmental Protection Agency, and municipal governments and local businesses have supported Nature Cleaners events. However, he is extremely cautious not to accept money or to allow sponsors to use Nature Cleaners in their advertising to avoid a perception that he or Nature Cleaners is benefiting from the interest they are receiving.

\section{Korean village groves restoration project}

In 2002, Nam-sun Park, former head of the village committee in Donghae, South Korea, led a group of citizens planting a village grove. Small groves of trees planted adjacent to villages historically have been used to break winds and high tides and as sites for cultural ceremonies. In Donghae, the village grove was planted in a space that, after being devastated by Typhoon Rusa, had been converted to a parking lot. Restoration of the site was a collaborative effort among villagers, the local government property owners, and the national nongovernmental organization Forest for Life. The city of Donghae subsequently developed new policies to support the management of the restored village grove (Lee 2014, Lee and Krasny 2015).

Both Park and the director of Forest for Life see the Donghae restoration project as part of a national citizens' movement that is shedding light on the value of village groves. This movement is garnering attention from researchers and from the Korean Forest Service, which developed a master plan resulting in the restoration of more than 60 village groves.

Park commented: "I started such restoration projects to hand the land over to my children and grandchildren to enjoy school trips there as I did" (participant response, 2013, online course). Although Park and other local residents have memories of seaside village groves, they lacked documents outlining restoration practices. Thus, they collected old maps and pictures of the site and visited Japan to learn about seaside natural park restoration. Rebuilding the village grove has meanings related not just to planting trees but also to building community and empowering local people, including elderly residents.

\section{Oyster gardening}

The nonprofit NY/NJ Baykeeper's oyster gardening program trains volunteers to work with scientists to place cages with young oysters at locations throughout the estuary and to monitor the oysters' growth and survival (Krasny et al. 2014a). Their goal is to restore oyster populations in the NYC estuary, thus "allowing this keystone species to begin playing its natural role in cleansing our waterways" (http://www.nynjbaykeeper.org/). Oysters played a critical role in NYC's cultural, economic, and environmental history and were once iconic of NYC as a place (Kurlansky 2006). Today, oyster gardeners attribute meanings to oysters and to the NYC estuary that tightly couple cultural/historical and ecological elements of the estuary: oysters as filter feeders or the "liver" of the estuary, oysters as a "missing link" between the city's inhabitants and its lost nature, and oysters as a symbol of NYC's "forgotten waterfront" that once was the center of a "growing and bustling city" (Krasny et al. 2014a). Reinforcing this notion is the idea of oysters as the "hotdog" of a bygone era, referring to the fact that earlier street stands selling oysters have been replaced with today's hotdog stands. In short, oyster gardeners see their practice as restoring a once-healthy estuary and the lost connections and meanings it supported. Because we did not interview leaders of this practice, we have not included the competence element.

\section{Friends of the Gorge}

The Cornell University Friends of the Gorge (FOG) student organization was founded by M.E.K. (first author) in response to what she viewed as the university's neglect of Cornell's unique campus natural areas and related safety issues (Krasny and Delia 2014 , in press). For years, trails had been left in poor condition, and little action was taken to stem drownings and suicides in the gorges. Then, after a drowning in 2008, the university attempted to block access to a popular hiking trail by installing fences and a gate. Shortly thereafter, following a cluster of student suicides in the gorges, the administration undertook a university-wide initiative to develop policies that balanced physical safety with recreational access. FOG, whose mission integrates stewardship, recreation, and safety in the campus gorges, contributed to this effort and was a strong voice for maintaining safe recreational access to the gorges, i.e., hiking but not swimming. In addition to contributing to university policy, FOG students are involved in hiking and stewardship, including trail maintenance, litter cleanups, and tree planting.

Although M.E.K. is the faculty adviser for FOG, each year a new student is elected president by student members. Thus, leadership is assumed by the student presidents, who have exhibited different competencies, with some taking an active role to link with other groups to engage in policy and natural area management, and others focusing more on getting students together for hiking in the campus natural areas. Students associate FOG stewardship and recreation activities with relief from stress by spending time in nature, with giving something back to the university and more broadly their country, and as an opportunity for small but 
Table 1. Practice elements in eight case practices.

\begin{tabular}{|c|c|c|c|c|}
\hline \multirow[t]{2}{*}{ Practice Name } & \multicolumn{3}{|c|}{ Practice Elements } & \multirow[t]{2}{*}{ Practice Description } \\
\hline & Competencies & Meanings & Resource & \\
\hline $\begin{array}{l}\text { Gateway } \\
\text { Environmental } \\
\text { Initiative }\end{array}$ & $\begin{array}{l}\text { Articulate vision } \\
\text { Advocacy } \\
\text { Build collaborations with } \\
\text { other organizations, } \\
\text { agencies, and private } \\
\text { sector }\end{array}$ & $\begin{array}{l}\text { Stream flowing through site } \\
\text { represents connecting diverse } \\
\text { neighborhoods bordering site } \\
\text { Nature center as hope and } \\
\text { empowerment }\end{array}$ & $\begin{array}{l}\text { 19-acre threatened } \\
\text { open space }\end{array}$ & $\begin{array}{l}\text { Conserve and steward natural area } \\
\text { dedicated to environmental education } \\
\text { and stewardship opportunities in } \\
\text { Winston Salem, North Carolina }\end{array}$ \\
\hline $\begin{array}{l}\text { Five Rivers } \\
\text { MetroParks }\end{array}$ & $\begin{array}{l}\text { Engage and supervise } \\
\text { volunteers } \\
\text { Tree planting }\end{array}$ & $\begin{array}{l}\text { Intergenerational bonding } \\
\text { Attachment to trees }\end{array}$ & $\begin{array}{l}\text { Multiple metropolitan } \\
\text { parks }\end{array}$ & $\begin{array}{l}\text { Restore native forest canopy in } \\
\text { metropolitan Dayton, Ohio }\end{array}$ \\
\hline $\begin{array}{l}\text { Tusten Heritage } \\
\text { Community } \\
\text { Garden }\end{array}$ & $\begin{array}{l}\text { Community activism } \\
\text { Articulate vision } \\
\text { Build collaborations with } \\
\text { other organizations, } \\
\text { agencies, and private } \\
\text { sector }\end{array}$ & $\begin{array}{l}\text { Heritage food growing practices } \\
\text { will transform future of region } \\
\text { Big Eddy market reflecting } \\
\text { history and natural history of } \\
\text { Delaware River }\end{array}$ & $\begin{array}{l}\text { Community garden at } \\
\text { center of regional } \\
\text { initiative }\end{array}$ & $\begin{array}{l}\text { Community gardening in small town } \\
\text { in rural upstate New York and related } \\
\text { regional sustainable economic } \\
\text { development efforts }\end{array}$ \\
\hline Seeding the City & $\begin{array}{l}\text { Green module } \\
\text { development } \\
\text { Motivating volunteers } \\
\text { Integrating art with } \\
\text { gardening } \\
\text { Advocacy }\end{array}$ & $\begin{array}{l}\text { Rooftop occupations } \\
\text { Islands of community in the sky } \\
\text { Create sense of place and } \\
\text { community among transient } \\
\text { apartment dwellers }\end{array}$ & $\begin{array}{l}\text { Rooftops distributed } \\
\text { throughout the city }\end{array}$ & $\begin{array}{l}\text { Rooftop gardening using ready-made } \\
\text { modules in New York City }\end{array}$ \\
\hline Nature Cleaners & $\begin{array}{l}\text { Guidance for volunteers } \\
\text { and groups not previously } \\
\text { engaged in civil society } \\
\text { Ability to work within } \\
\text { political system not } \\
\text { accustomed to civil } \\
\text { society groups } \\
\text { Integrity }\end{array}$ & $\begin{array}{l}\text { Cleaning nature } \\
\text { Educating others about cleaning } \\
\text { nature } \\
\text { Creating culture of not littering } \\
\text { Connecting with others } \\
\text { Teamwork } \\
\text { Cleaning up the country }\end{array}$ & $\begin{array}{l}\text { Small and large parks, } \\
\text { urban forest, historic } \\
\text { sites, and other open } \\
\text { space }\end{array}$ & $\begin{array}{l}\text { Clean up litter in natural and other } \\
\text { high visibility and high use areas in } \\
\text { Iran }\end{array}$ \\
\hline $\begin{array}{l}\text { Korean village } \\
\text { groves }\end{array}$ & $\begin{array}{l}\text { Engage villagers in } \\
\text { natural resource } \\
\text { management } \\
\text { Collaborate with local } \\
\text { government and national } \\
\text { nongovernmental } \\
\text { organization }\end{array}$ & $\begin{array}{l}\text { Citizen movement } \\
\text { Reconnecting to nature and } \\
\text { cultural traditions }\end{array}$ & $\begin{array}{l}1 \text {-acre parking lot } \\
\text { adjacent to ocean } \\
\text { prone to destruction by } \\
\text { typhoons }\end{array}$ & $\begin{array}{l}\text { Restore seaside village groves and } \\
\text { revive cultural ceremonies in small } \\
\text { city in South Korea }\end{array}$ \\
\hline Oyster gardening & Information not available & $\begin{array}{l}\text { Restoring ecological and social } \\
\text { functions of estuary } \\
\text { Oysters as liver of the estuary, } \\
\text { former hotdog stand, and missing } \\
\text { link between city inhabitants and } \\
\text { city's lost nature }\end{array}$ & $\begin{array}{l}\text { New York City estuary } \\
\text { and oysters living in } \\
\text { estuary }\end{array}$ & $\begin{array}{l}\text { Place and monitor artificial oyster } \\
\text { reefs in New York City estuary }\end{array}$ \\
\hline Friends of Gorge & $\begin{array}{l}\text { Organize events with } \\
\text { multiple groups } \\
\text { Engage students in } \\
\text { stewardship and } \\
\text { recreation }\end{array}$ & $\begin{array}{l}\text { Giving back through volunteer } \\
\text { stewardship } \\
\text { Relief from stress through time } \\
\text { spent in nature }\end{array}$ & $\begin{array}{l}\text { Scenic campus natural } \\
\text { area gorges }\end{array}$ & $\begin{array}{l}\text { Stewardship and recreation in natural } \\
\text { areas on university campus in small } \\
\text { city in upstate New York }\end{array}$ \\
\hline
\end{tabular}

meaningful action in a large and at times seemingly impersonal institution.

\section{PRACTICE ELEMENTS IN CIVIC ECOLOGY \\ PRACTICES}

Analysis of the eight cases reveals that the ability to articulate a vision, build collaborations, and manage volunteers, which we refer to as "social" and "communication" competencies, were important across the practices and mentioned more often than technical competencies such as tree planting and creating modular plantings for green roofs (Table 1). Social competencies ranged from individuals with a limited set of partners who focused on recruiting and managing volunteers, i.e., FRMP and FOG, to those who built multiple collaborations to form city-, region-, or nationwide networks of public and private partners, i.e., GEI, Tusten Heritage Community Garden, and Nature Cleaners. Communication competencies included articulating a vision about nature and how it is connected to human, community, and regional well-being, i.e., GEI and Tusten Heritage Community Garden, or a more advocacy-oriented message like "occupy 
rooftops," i.e., STC. An interesting case was the leader of Nature Cleaners in Iran, who assumed the role of an elder statesman and devoted significant effort to helping volunteers learn to work as a team. Further, as leader of a project that attempted to gain visibility for its efforts by conducting events at popular sites, yet in a country that lacks a tradition of civil society, Nadjariun walked a fine line between advocacy and making it clear that the group focused only on environmental cleanup and education.

The leader of the Tusten Heritage Community Garden used her ability to build relationships and articulate a vision to leverage the potential threat caused by hydraulic fracking in expanding her practice. In particular, she expanded a community gardening practice to a larger regional initiative, which pitted sustainable local farming traditions against an extractive economy dominated by mining. Thus, this case provides evidence of a disturbance propelling participants to reflect on and expand their practice (Engeström 2001). Practices may also change in the absence of a threat, potentially decreasing in scope. For example, FOG was very active in university policy making during the period immediately after a suicide cluster in the campus gorges but since has evolved into a much more limited set of recreation and stewardship activities.

Meanings or the values attached to the practice and resource were articulated by leaders such as E.M. who talked about rooftop gardens as islands of community in the sky. In some cases, participants helped produce meanings as when FOG students and Nature Cleaners volunteers talked about their practice in terms of giving back to or cleaning up their local place and larger country; such coproduction of meanings is consistent with literature on coproduction of practice innovations by users and consumers or practitioners and policy makers (Pantzar and Shove 2010, Seyfang and Haxeltine 2012). Leaders and participants variously ascribed meaning to the resource that was the focus of the practice, e.g., the river flowing through the GEI site connecting habitats and neighborhoods, and to the practice itself, e.g., the GEI practice creating awareness of the value of natural space. In a study of tree-planting civic ecology practices in post-Katrina New Orleans, Tidball (2014) similarly found that participants attributed symbolic meanings to trees (i.e., the resource), as well as to tree planting as a ritual or practice. Finally, we found that meanings attributed to both the resource and the practice often integrated social and ecological components. So, for example, the oyster was both the "liver" that filtered pollutants from the estuary and New Yorkers' once-favored food, i.e., the "hotdog" of its day. These linked social-ecology meanings are consistent with notions of social-ecological memories, symbols, and rituals in civic ecology practices (Barthel et al. 2014, Tidball 2014) and socialecological meanings in studies of rural forest management (Michon et al. 2012) but have not been a focus of previous studies using practice theory.

Given the importance of the physical or biological resource in civic ecology practices, and our desire to limit the number of elements, we focused on the resource rather than technology for the material element. The resource element varied along three dimensions: type, scale, and spatial configuration (Box 1). Leaders took advantage of the uniqueness of the resource in attributing meanings and motivating engagement, including oysters as livers of the estuary and village groves that historically had served as sites for cultural ceremonies in South Korea.
Box 1:

Summary of practice elements from all cases.

Competencies

- Advocacy

- Articulate larger vision

- Create art

- Mobilize others

- Build relationships

- Build collaborations with local residents, multiple organizations, agencies, and private sector

- Technical, e.g., tree planting and care and green roof module development

- Volunteer management including conflict resolution

Meanings

- Meanings attributed to the resource, e.g., oyster as liver of estuary, islands of community in the sky, and connecting neighborhoods bordering the site through a river that runs through the site

- Meanings attributed to the practice, e.g., giving back, intergenerational bonding, heritage food-growing practices transforming the future of the regional economy, and cleaning the country

Resource

- Type: land; water; building, i.e., rooftop; animal, i.e., oyster

- Scale: small plots to entire region

- Spatial configuration: noncontiguous, e.g., rooftops and plots of land; contiguous, e.g., estuary

\section{IMPLICATIONS OF PRACTICE THEORY IN STUDIES OF URBAN STEWARDSHIP}

Our results suggest that practice theory may be a useful means for understanding a broader set of practices than consumer behaviors. In contrast to consumer behaviors such as reducing home energy use, stewardship behaviors do not result in an economic benefit to participants but instead entail sustained volunteer engagement to produce a public good. This presents a set of challenges to those attempting to sustain the practice, which may explain why social and communication competencies such as articulating a vision, building relationships, and managing volunteers emerged as important. Meanings reflecting values that participants attach to the resource and their work, such as cleaning up an estuary, an open space, or even a country, may also serve to sustain and expand practices focused on creating a public good rather than on individual behaviors.

The typology we developed related to type, scale, and physical contiguity of the resource element may provide insights into 
understanding the other practice elements and urban stewardship practices more broadly. For example, organizations attempting to bridge across multiple practices might want to consider the nature of the resource. Are the practices all located along a river or lake that connects them physically and symbolically, or are they focused on small noncontiguous patches like community gardens? In the Bronx River restoration efforts in NYC, bridging organizations were able to leverage meanings associated with the river as a physical resource to connect multiple stewardship efforts, whereas bridging organizations working with community gardens leverage meanings related to social issues like food justice (Krasny and Tidball 2015). A Swedish initiative attempted to use meanings associated with Stockholm's historic royal parks as a means to bridge across multiple conservation initiatives; however, in this case, a single meaning was unable to cut across and thus link disparate citizen and government-directed stewardship efforts (Ernstson et al. 2008).

Whereas our decision to focus the material element on the physical resource enabled us to better understand the variation in resources, it may have limited our ability to understand the role of technologies. Other practice theory studies have shown how a new technology can transform consumer practices (Pantzar and Shove 2010, Gram-Hanssen 2011). We found that the modular units that enabled rooftop gardening and the artificial oyster reefs that allowed oyster gardening provide examples of how technologies can enable new civic ecology practices. Ongoing research into inexpensive "do-it-yourself" and open technologies for monitoring air and water quality, food production, and ecosystem services provision by trees suggests that technologies may enable civic ecology practices to incorporate outcome monitoring; such technologies could enable adaptation and expansion of practices based on monitoring results (Silva and Krasny 2014). Social networking technologies are also a critical factor allowing the expansion of civic ecology practices; examples include how Facebook enabled the rapid spread of Nature Cleaners across cities in Iran and of "The Ugly Indian," a practice that engages volunteers in converting trash-strewn spaces to pocket parks with green elements, garbage cans, and urinals in India (http://www.theuglyindian.com/).

The notion of communities of practice has also been used to study urban stewardship practices. The use of practice theory shifts the focus from understanding the process of learning to understanding the practice and its elements. Further, whereas studies using the communities of practice framework lend themselves to understanding how participants in a practice or learners change over time, research guided by practice theory has examined how an actual practice changes, through recombining and repurposing different elements. For example, Pantzar and Shove (2010) showed how recreational walkers repurposed the meanings and skills related to a new technology, i.e., carbon-fiber walking sticks, to create a new practice called Nordic walking. Despite the difference in emphasis, studies using the community of practice lens have produced findings consistent with our findings. Research using a communities of practice perspective found that learning about self-organization, defined as managing social cohesion, division of labor, collective responsibilities, decision structures, involvement of new members, and engaging with the public, was one of four learning streams in public access gardens in Berlin, along with learning about gardening and ecological conditions, the politics of space, and social enterprise (Bendt et al. 2013). Such learning about self-organization is similar to our finding about the importance of social competencies.

\section{CONCLUSION}

We expand past work in practice theory by applying it to a new type of practice, i.e., civic ecology practices. Further, we add a new lens to a growing body of literature that seeks to understand urban self-organized stewardship practices, including how they emerge and expand, their constraints, and their outcomes for individuals, communities, and social-ecological systems.

In this initial effort to apply practice theory, we used only three elements: competencies, meanings, and resource. Based on our findings, we recommend that future studies incorporate a technology element. The technology element will enable investigation into how new habitat restoration (e.g., artificial oyster reefs), monitoring, and social networking technologies facilitate the emergence and growth of civic ecology practices. Because of the importance of social and communication skills in urban volunteer stewardship practice, consideration might also be given to whether these competencies should be treated as a separate element.

Practice leaders, scientists, and individuals attempting to bridge across practices could apply practice theory to understanding how practice elements might help constrain and enable their efforts. For example, local politicians wanting to use civic ecology practices to help provision ecosystem services might want to consider the existing competencies of stewards, the meanings stewards attribute to their work and to the resource, and the technologies that are accessible and acceptable to the stewards given their competencies and the meanings that motivate them.

A shortcoming of this exploratory work is our focus on individual elements with little regard to practice theory's treatment of how the constellation of elements is what ultimately defines a practice. In the future, practices might be analyzed not only by their individual elements but also by how the various elements or subelements interact. For example, one might examine cooccurrence of certain types of resources, competencies, and meanings, such as whether activist leaders or leaders with artistic competencies articulate different types of visions, or whether noncontiguous and contiguous resources require different competencies. This might enable us to develop a richer typology of civic ecology practices than, for example, listing different stewardship behaviors, e.g., community gardening and tree planting. In short, we contend that practice theory is worthy of further exploration alongside other approaches to understanding urban stewardship, with the goal of developing a deeper understanding of how such practices emerge, grow, and are sustained over time.

Responses to this article can be read online at: http://www.ecologyandsociety.org/issues/responses. $\mathrm{php} / 7345$ 


\section{Acknowledgments:}

Funding for this research was contributed by the U.S. Department of Agriculture National Institute for Food and Agriculture administered through Cornell University, multistate project NECC1011. The Civic Ecology online course was developed under Assistance Agreement No. NT-83497401 awarded by the U.S. Environmental Protection Agency (EPA). It has not been formally reviewed by the EPA. The views expressed are solely those of the authors, and the EPA does not endorse any products or commercial services mentioned.

\section{LITERATURE CITED}

Andersson, E., S. Barthel, and K. Ahrné. 2007. Measuring socialecological dynamics behind the generation of ecosystem services. Ecological Applications 17:1267-1278. http://dx.doi.org/10.1890/06-1116.1

Barthel, S. 2006. Sustaining urban ecosystem services with local stewards participation in Stockholm (Sweden). Pages 305-320 in B. Tress, G. Tress, G. Fry, and P. Opdam, editors. From landscape research to landscape planning: aspects of integration, education and application. Wageningen UR Frontis Series. Springer, Dordrecht, The Netherlands.

Barthel, S., C. Folke, and J. Colding. 2010. Social-ecological memory in urban gardens - retaining the capacity for management of ecosystem services. Global Environmental Change 20:255-265. http://dx.doi.org/10.1016/j.gloenvcha.2010.01.001

Barthel, S., J. Parker, C. Folke, and J. Colding. 2014. Urban gardens: pockets of social-ecological memory. Pages 145-158 in K. G. Tidball and M. E. Krasny, editors. Greening in the red zone. Springer, Dordrecht, The Netherlands. http://dx.doi. org/10.1007/978-90-481-9947-1_11

Bendt, P., S. Barthel, and J. Colding. 2013. Civic greening and environmental learning in public-access community gardens in Berlin. Landscape and Urban Planning 109:18-30. http://dx.doi. org/10.1016/j.landurbplan.2012.10.003

Colding, J., and S. Barthel. 2013. The potential of 'Urban Green Commons' in the resilience building of cities. Ecological Economics 86:156-166. http://dx.doi.org/10.1016/j.ecolecon.2012.10.016

Colding, J., S. Barthel, P. Bendt, R. Snep, W. van der Knaap, and H. Ernstson. 2013. Urban green commons: insights on urban common property systems. Global Environmental Change 23:1039-1051. http://dx.doi.org/10.1016/j.gloenvcha.2013.05.006

Davidson, D. J. 2010. The applicability of the concept of resilience to social systems: some sources of optimism and nagging doubts. Society \& Natural Resources: An International Journal 23:1135-1149. http://dx.doi.org/10.1080/08941921003652940

Dickinson, J. L. 2009. The people paradox: self-esteem striving, immortality ideologies, and human response to climate change. Ecology and Society 14(1): 34. [online] URL: http://www. ecologyandsociety.org/vol14/iss1/art34/

Elmqvist, T., M. Fragkias, J. Goodness, B. Güneralp, P. J. Marcotullio, R. I. McDonald, S. Parnell, M. Schewenius, M. Sendstad, K. C. Seto, and C. Wilkinson. 2013. Urbanization, biodiversity and ecosystem services: challenges and opportunities.
Springer, Dordrecht, The Netherlands. http://dx.doi. org/10.1007/978-94-007-7088-1

Engeström, Y., editor. 1987. Learning by expanding: an activitytheoretical approach to developmental research. Orienta-Konsultit, Helsinki, Finland.

Engeström, Y. 2001. Expansive learning at work: toward an activity-theoretical conceptualization. Journal of Education and Work 14:133-156. http://dx.doi.org/10.1080/13639080020028747

Engeström, Y., R. Miettinen, and R.-L. Punamäki, editors. 1999. Perspectives on activity theory. Cambridge University Press, Cambridge, UK. http://dx.doi.org/10.1017/CBO9780511812774

Ernstson, H., and T. Elmqvist. 2011. Globalization, urban ecosystems and social-ecological innovations: a comparative network analytic approach. Stockholm University, Stockholm, Sweden.

Ernstson, H., S. Sörlin, and T. Elmqvist. 2008. Social movements and ecosystem services - the role of social network structure in protecting and managing urban green areas in Stockholm. Ecology and Society 13(2): 39. [online] URL: http://www. ecologyandsociety.org/vol13/iss2/art39/

Fisher, D. R., L. K. Campbell, and E. S. Svendsen. 2012. The organisational structure of urban environmental stewardship. Environmental Politics 21:26-48. http://dx.doi.org/10.1080/0964$\underline{4016.2011 .643367}$

Francis, M., L. Cashdan, and L. Paxson. 1984. Community open spaces. Island, Washington, D.C., USA.

Geels, F. W., and J. Schot. 2007. Typology of sociotechnical transition pathways. Research Policy 36:399-417. http://dx.doi. org/10.1016/j.respol.2007.01.003

Goddard, M. A., A. J. Dougill, and T. G. Benton. 2010. Scaling up from gardens: biodiversity conservation in urban environments. Trends in Ecology and Evolution 25:90-98.

Golshani, Z., and M. E. Krasny. 2013. Civic ecology practice in Iran: the case of the Nature Cleaners. North American Association for Environmental Education, Baltimore, Maryland, USA.

Gram-Hanssen, K. 2010. Standby consumption in households analyzed with a practice theory approach. Journal of Industrial Ecology 14:150-165. http://dx.doi.org/10.1111/j.1530-9290.2009.00194. $\underline{x}$

Gram-Hanssen, K. 2011. Understanding change and continuity in residential energy consumption. Journal of Consumer Culture 11:61-78. http://dx.doi.org/10.1177/1469540510391725

Hargreaves, T. 2011. Practice-ing behaviour change: applying social practice theory to pro-environmental behaviour change. Journal of Consumer Culture 11:79-99. http://dx.doi. org/10.1177/1469540510390500

Kemmis, S., and R. Mutton. 2012. Education for sustainability (EfS): practice and practice architectures. Environmental Education Research 18:187-207. http://dx.doi.org/10.1080/13504$\underline{622.2011 .596929}$

Krasny, M. E., S. R. Crestol, K. G. Tidball, and R. C. Stedman. 2014a. New York City's oyster gardeners: memories and meanings 
as motivations for volunteer environmental stewardship. Landscape and Urban Planning 132:16-25. http://dx.doi. org/10.1016/j.landurbplan.2014.08.003

Krasny, M. E., and J. Delia. In press. Natural area stewardship as part of campus sustainability. Journal of Cleaner Production. http://dx.doi.org/10.1016/j.jclepro.2014.04.019

Krasny, M. E., and J. Delia. 2014. Campus sustainability and natural area stewardship: student involvement in adaptive comanagement. Ecology and Society 19(3): 27. http://dx.doi. org/10.5751/ES-06787-190327

Krasny, M. E., C. Lundholm, E. Lee, S. Shava, and H. Kobori. 2013. Urban landscapes as learning arenas for sustainable management of biodiversity and ecosystem services. Pages 629-664 in T. Elmqvist, M. Fragkias, J. Goodness, B. Güneralp, P. J. Marcotullio, R. I. McDonald, S. Parnell, M. Sendstad, M. Schewenius, K. C. Seto, and C. Wilkinson, editors. Urbanization, biodiversity and ecosystem services: challenges and opportunities. Springer, New York, New York, USA.

Krasny, M. E., A. Russ, K. G. Tidball, and T. Elmqvist. $2014 b$. Civic ecology practices: participatory approaches to generating and measuring ecosystem services in cities. Ecosystem Services 7:177-186. http://dx.doi.org/10.1016/j.ecoser.2013.11.002

Krasny, M. E., and K. G. Tidball. 2012. Civic ecology: a pathway for Earth stewardship in cities. Frontiers in Ecology and the Environment 10:267-273. http://dx.doi.org/10.1890/110230

Krasny, M. E., and K. G. Tidball. 2015. Civic ecology: adaptation and transformation from the ground up. MIT Press, Cambridge, Massachusetts, USA.

Kudryavtsev, A., M. E. Krasny, and R. C. Stedman. 2012. The impact of environmental education on sense of place among urban youth. Ecosphere 3:29. http://dx.doi.org/10.1890/ ES11-00318.1

Kurlansky, M. 2006. The big oyster: history on the half shell. Ballantine Books, New York, New York, USA.

Lee, E. 2014. Reconstructing village groves after a typhoon in Korea. Pages 159-162 in K. G. Tidball and M. E. Krasny, editors. Greening in the red zone. Springer, Dordrecht, The Netherlands. http://dx.doi.org/10.1007/978-90-481-9947-1 12

Lee, E., and M. E. Krasny. 2015. The role of social learning for social-ecological systems in Korean village groves restoration. Ecology and Society 20(1): 42. http://dx.doi.org/10.5751/ ES-07289-200142

McPhearson, T., and K. G. Tidball. 2014. Disturbances in urban social-ecological systems: niche opportunities for environmental education. Pages 193-230 in M. E. Krasny and J. Dillon, editors. Trading zones in environmental education: creating transdisciplinary dialogue. Peter-Lang, New York, New York, USA.

Michon, G., B. Romagny, L. Auclair, and M. Deconchat. 2012. Forests as patrimonies? From theory to tangible processes at various scales. Ecology and Society 17(3): 7. http://dx.doi. org/10.5751/ES-04896-170307

Miettinen, R., S. Paavola, and P. Pohjola. 2012. From habituality to change: contribution of activity theory and pragmatism to practice theories. Journal for the Theory of Social Behaviour 42:345-360. http://dx.doi.org/10.1111/j.1468-5914.2012.00495.x

Olsson, P., C. Folke, V. Galaz, T. Hahn, and L. Schultz. 2007. Enhancing the fit through adaptive comanagement: creating and maintaining bridging functions for matching scales in the Kristianstads Vattenrike Biosphere Reserve Sweden. Ecology and Society 12(1): 28. [online] URL: http://www.ecologyandsociety. org/vol12/iss1/art28/

Pantzar, M., and E. Shove. 2010. Understanding innovation in practice: a discussion of the production and re-production of Nordic Walking. Technology Analysis \& Strategic Management 22:447-461. http://dx.doi.org/10.1080/09537321003714402

Pataki, D. E., M. M. Carreiro, J. Cherrier, N. E. Grulke, V. Jennings, S. Pincetl, R. V. Pouyat, T. H. Whitlow, and W. C. Zipperer. 2011. Coupling biogeochemical cycles in urban environments: ecosystem services, green solutions, and misconceptions. Frontiers in Ecology and the Environment 9:27-36. http://dx.doi.org/10.1890/090220

Reckwitz, A. 2002. Toward a theory of social practices: a development in culturalist theorizing. European Journal of Social Theory 5:243-263. http://dx.doi.org/10.1177/13684310222225432

Sassen, S., and N. Dotan. 2011. Delegating, not returning, to the biosphere: how to use the multi-scalar and ecological properties of cities. Global Environmental Change 21:823-834. http://dx.doi. org/10.1016/j.gloenvcha.2011.03.018

Schatzki, T. R. 2000. Introduction: practice theory. Pages 1-14 in T. R. Schatzki, K. Knorr-Cetina, and E. Savigny, editors. Practice turn in contemporary theory. Routledge, Florence, Kentucky, USA.

Schatzki, T. R. 2002. The site of the social. A philosophical account of the constitution of social life and change. Pennsylvania State University Press, State College, Pennsylvania, USA.

Seyfang, G., and A. Haxeltine. 2012. Growing grassroots innovations: exploring the role of community-based initiatives in governing sustainable energy transitions. Environment and Planning C: Government and Policy 30:381-400. http://dx.doi. org/10.1068/c10222

Seyfang, G., A. Haxeltine, T. Hargreaves, and N. Longhurst. 2010. Energy and communities in transition - towards a new research agenda on agency and civil society in sustainability transitions. Centre for Social and Economic Research on the Global Environment (CSERGE) Working Paper, Environmental Decision Making (EDM) 10-13. CSERGE, University of East Anglia, Norwich, UK.

Shove, E., and M. Pantzar. 2005. Consumers, producers and practices: understanding the invention and reinvention of Nordic walking. Journal of Consumer Culture 5:43-64. http://dx.doi. org/10.1177/1469540505049846

Shove, E., and G. Walker. 2010. Governing transitions in the sustainability of everyday life. Research Policy 39:471-476. http:// dx.doi.org/10.1016/j.respol.2010.01.019

Silva, P., and M. E. Krasny. 2014. Parsing participation: models of engagement for outcomes monitoring in urban stewardship. 
Local Environment: The International Journal of Justice and Sustainability. http://dx.doi.org/10.1080/13549839.2014.929094

Sirianni, C., and L. A. Friedland. 2005. The civic renewal movement: community building and democracy in the United States. Charles F. Kettering Foundation, Dayton, Ohio, USA.

Spaargaren, G. 2011. Theories of practices: agency, technology, and culture. Exploring the relevance of practice theories for the governance of sustainable consumption practices in the new world-order. Global Environmental Change 21:813-822. http://dx. doi.org/10.1016/j.gloenvcha.2011.03.010

Svendsen, E. S., and L. Campbell. 2008. Urban ecological stewardship: understanding the structure, function and network of community-based land management. Cities and the Environment 1:1-32.

Svendsen, E. S., and L. K. Campbell. 2014. Community-based memorials to September 11, 2001: environmental stewardship as memory work. Pages 339-355 in K. G. Tidball and M. E. Krasny, editors. Greening in the red zone. Springer, Dordrecht, The Netherlands. http://dx.doi.org/10.1007/978-90-481-9947-1 25

Tidball, K. G. 2014. Trees and rebirth: social-ecological symbols and rituals in the resilience of post-Katrina New Orleans. Pages 257-296 in K. G. Tidball and M. E. Krasny, editors. Greening in the red zone. Springer, Dordrecht, The Netherlands. http://dx.doi. org/10.1007/978-90-481-9947-1 20

Tidball, K. G., and M. E. Krasny, editors. 2014. Greening in the red zone. Springer, Dordrecht, The Netherlands. http://dx.doi. org/10.1007/978-90-481-9947-1

Tidball, K. G., M. E. Krasny, E. Svendsen, L. Campbell, and K. Helphand. 2010. Stewardship, learning, and memory in disaster resilience. Environmental Education Research 16:591-609. http:// dx.doi.org/10.1080/13504622.2010.505437

Tidball, K., and R. Stedman. 2013. Positive dependency and virtuous cycles: from resource dependence to resilience in urban social-ecological systems. Ecological Economics 86:292-299. http://dx.doi.org/10.1016/j.ecolecon.2012.10.004

Warde, A. 2005. Consumption and theories of practice. Journal of Consumer Culture 5:131-153. http://dx.doi.org/10.1177/14695$\underline{40505053090}$

Wenger, E., R. McDermott, and W. M. Snyder. 2002. Cultivating communities of practice. Harvard Business School Press, Cambridge, Massachusetts, USA.

Young Foundation. 2012. Social innovation overview: a deliverable of the project "The theoretical, empirical and policy foundations for building social innovation in Europe" (TEPSIE). European Commission, Seventh Framework Programme, DirectorateGeneral Research, Brussels, Belgium. 